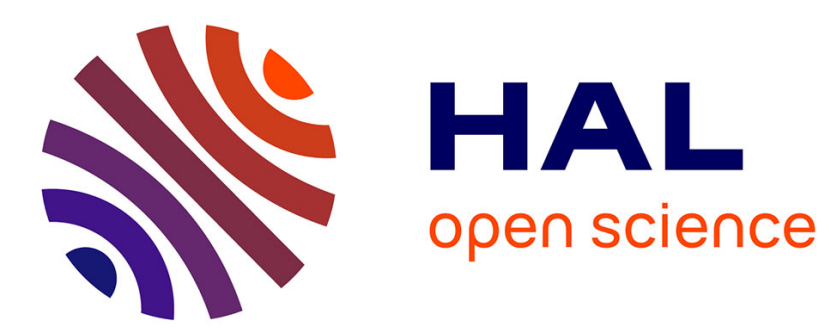

\title{
How can f-block mono-cations behave as Mono-Cations of d-block transition metals?
}

Alexandre Quemet, René Brennetot, Jean-Yves Salpin, Alvaro Cimas, Colin J. Marsden, Jeanine Tortajada, Pierre Vitorge

\section{To cite this version:}

Alexandre Quemet, René Brennetot, Jean-Yves Salpin, Alvaro Cimas, Colin J. Marsden, et al.. How can f-block mono-cations behave as Mono-Cations of d-block transition metals?. European Journal of Inorganic Chemistry, 2012, 2012 (22), pp.3551-3555. 10.1002/ejic.201200455 hal-00760023

\section{HAL Id: hal-00760023 \\ https://hal.science/hal-00760023}

Submitted on 8 Oct 2018

HAL is a multi-disciplinary open access archive for the deposit and dissemination of scientific research documents, whether they are published or not. The documents may come from teaching and research institutions in France or abroad, or from public or private research centers.
L'archive ouverte pluridisciplinaire HAL, est destinée au dépôt et à la diffusion de documents scientifiques de niveau recherche, publiés ou non, émanant des établissements d'enseignement et de recherche français ou étrangers, des laboratoires publics ou privés. 


\title{
How can f-Block Mono-Cations Behave as Mono-Cations of d-Block Transition Metals?
}

\author{
Alexandre Quemet, ${ }^{[a]}$ Rene Brennetot, ${ }^{[a]}$ Jean-Yves Salpin, ${ }^{[b, c]}$ Alvaro Cimas, ${ }^{[\mathrm{d}]}$ Colin Marsden,,$[\mathrm{e}, \mathrm{f}]$ \\ Jeanine Tortajada, ${ }^{[\mathrm{b}, \mathrm{c}]}$ and Pierre Vitorge ${ }^{[\mathrm{c}, \mathrm{g}]}$
}

Keywords: Density functional calculations / Ion-molecule reactions / Lanthanides / Actinides / Multiple bonds

\begin{abstract}
The electronic structures of $\mathrm{LnNH}^{+}$is studied by DFT (B3LYP) quantum calculation for the $\mathrm{Ln}=\mathrm{La}$, Eu and $\mathrm{Gd} 4 \mathrm{f}$-block elements (lanthanides). $\mathrm{Ln} \equiv \mathrm{N}$ triple bonds of essentially d-character are formed for $\mathrm{La}$ and $\mathrm{Gd}$ explaining why $\mathrm{La}^{+}$and $\mathrm{Gd}^{+}$behave like dblock elements as experimentally evidenced by mass spectrometry, and why the $\mathrm{Ln}^{+}$reactivity is correlated with its electron-promotion energy: the present theoretical study is a support to such correlation and qualitative knowledge. The $\mathrm{Ln}^{+}+\mathrm{NH}_{3} \rightarrow \mathrm{LnNH}_{3}{ }^{+} \rightarrow$ transition state $\rightarrow \mathrm{HLn}=\mathrm{NH}_{2}^{+} \rightarrow$ transition state $\rightarrow \mathrm{Ln} \equiv \mathrm{NH}^{+}+\mathrm{H}_{2}$ reaction pathway is calculated.
\end{abstract}

The formation of $\mathrm{HLn}=\mathrm{NH}_{2}^{+}$corresponds to the formation of new covalent bonds associated with more electron pairing, and corresponding lowering of the spin multiplicity -spin crossing reaction. It is in this step that low electron-promotion energy is required to promote an $\mathrm{Ln} 4 \mathrm{f}$ electron onto an $\mathrm{Ln} 5 \mathrm{~d}$ orbital as typically for $\mathrm{La}^{+}$and $\mathrm{Gd}^{+}$. Similar geometry, bonding and electronic cofiguration are calculated for $\mathrm{NpNH}^{+}$-an actinide complex observed by mass spectrometry- with higher participation of $5 \mathrm{f}$-valence orbitals $(20 \%$ and $25 \%$ for the $\sigma$ and $\pi$ bonds) as compared to the $4 \mathrm{f}$-valence orbitals (3\% and $8 \%$ ) of $\mathrm{GdNH}^{+}: \mathrm{Gd}^{+}$and $\mathrm{Np}^{+}$are the only lanthanide and actinide cations with two non-f-valence electrons -one $\mathrm{s}$ and one $\mathrm{d}$ - in their ground states. [a] Laboratoire d'Analyse en Soutien aux Exploitants, CEA, DEN, DPC, SEARS, Saclay F-91991 Gif-sur-Yvette, France

Fax: +33169084323

E-mail: alexandre.quemet@cea.fr, rene.brennetot@cea.fr

[b] Université d'Evry Val d'Essonne, Laboratoire Analyse et Modélisation pour la Biologie et l'Environnement, Boulevard F. Mitterrand, 91025 Evry Cedex, France

[c] CNRS UMR 8587

[d] Centro de Investigação em Química, Department of Chemistry and Biochemistry, Faculty of Science, University of Porto, Rua do Campo Alegre, 687, P-4169-007 Porto, Portugal

[e] Université Paul Sabatier - Laboratoire de Physique Quantique, 118 route de Narbonne, F-31062 Toulouse cedex 4, France

[f] CNRS-UMR 5626

[g] Laboratoire de Radiolyse et de la Matière Organique, CEA, DEN, DPC, SECR, Saclay F-91991 Gif-sur-Yvette, France

E-mail : pierre.vitorge@cea.fr

Supporting information for this article is available on the WWW under http://www.eurjic.org/ or from the authors.

\section{Introduction}

Very different chemical behaviours have been evidenced in mass spectrometry analysis across the lanthanide ( $\mathrm{Ln})$ series of f-block elements: ${ }^{[1]}$ they can even behave as the Sc and Y d-block transition elements. ${ }^{[2]}$ It has been proposed that the reactivity of $\mathrm{Ln}^{+}$with gas in collision-reaction cells of mass spectrometers is correlated with its electron-promotion energy, the energy to obtain two non-f-valence electrons: the $4 \mathrm{f}^{\mathrm{n}} 5 \mathrm{~d}^{1} 6 \mathrm{~s}^{1}$ electronic configuration. This is in contrast with the well established picture for the chemistry of the f-block elements in condensed phases.

Most of the rare earths are lanthanides. La, the first lanthanide (Ln) in the periodic table is usually stable in the form of the $\mathrm{La}^{3+}$ hard cation, where $\mathrm{La}(\mathrm{III})$ is in its group oxidation state. The heavier Ln elements are f-block elements corresponding to the progressive filling of the $4 \mathrm{f}$-shell, with a few exceptions. The $4 \mathrm{f}-$ valence orbitals of $\mathrm{Ln}^{3+}$ do not easily participate to covalent bonding, consistently with the hard character of $\mathrm{Ln}^{3+}{ }^{3]}$ This accounts for the chemical analogy among the $\mathrm{Ln}^{3+}$ series -despite they have different electronic configurations, and with other hard trications of similar sizes as typically the $\left(\mathrm{An}^{3+}\right)$ tri-cations of the actinides, the series of the 5f-block elements.

This behaviour is in contrast with those of d-block transition elements, which ions often are rather soft -giving covalent bonds: their chemical behaviours are driven by their electronic configurations, which vary across the d-transition metal series. Nevertheless, another rare earth, Y, the transition element above La in the third column of the periodic table is a chemical analogue of La. $\mathrm{Y}^{3+}$ is of the size of a heavy $\mathrm{Ln}^{3+}$ as a result of the $\mathrm{Ln}$ contraction: it behaves as a heavy $\mathrm{Ln}^{3+}$, while $\mathrm{Sc}^{3+}-\mathrm{Sc}$ is the transition element above $\mathrm{Y}$ - is clearly smaller. ${ }^{[4]}$

$\mathrm{Sc}^{+}, \mathrm{Y}^{+}$or $\mathrm{Ln}^{+}$can be viewed as reduced $\mathrm{Sc}^{3+}, \mathrm{Y}^{3+}$ or $\mathrm{Ln}^{3+}$ stable hard ions, on which two electrons have been added: $\mathrm{M}^{3+}+$ $2 \mathrm{e}^{-} \rightarrow \mathrm{M}^{+}$. These two added electrons are not expected to be firmly retained in the monocations, since rare earths are usually more stable in the chemical forms of trications: meaning that these monocations are not especially expected to be of hard character in contrast with the stable trications. Namely, $\mathrm{Ln}^{+}$chemistry is not especially expected to be similar to that of the $\mathrm{Sc}^{+}$or $\mathrm{Y}^{+} \mathrm{d}$-cation, when the two $\mathrm{Ln}^{+}$extra electrons are in f-orbitals. Conversely, some analogy is not unexpected for those $\mathrm{Ln}^{+}$ions of similar electronic configurations as $\mathrm{Sc}^{+}$and $\mathrm{Y}^{+}$, namely when the promotion energy the $4 \mathrm{f}^{\mathrm{n}} 5 \mathrm{~d}^{1} 6 \mathrm{~s}^{1}$ electronic configuration is small. Note that d-valence orbitals can more easily be stabilized than the f-ones on covalent bonding, since the d-orbitals usually have greater spatial expansions, which facilitates covalency: electronic configuration can change on covalent bonding.

Experimental mass spectrometry showed the formation of $\mathrm{MNH}^{+}$, the key product for the reactivities of d-elements $\left(\mathrm{M}^{+}=\mathrm{Sc}^{+}\right.$ and $\left.\mathrm{Y}^{+}\right)$, and for $\mathrm{Ln}^{+}$ions of small $\left(\mathrm{La}^{+}\right)$or zero $\left(\mathrm{Gd}^{+}\right)$electronpromotion energies (see supporting information): ${ }^{[1 \mathrm{a}, 5]}$

$$
\mathrm{Ln}^{+}+\mathrm{NH}_{3} \rightarrow \mathrm{LnNH}^{+}+\mathrm{H}_{2}
$$

where the $\mathrm{Ln}^{+}$strong reducer produces $\mathrm{H}_{2}$ by inserting into $\mathrm{N}-\mathrm{H}$ bonds. The $\mathrm{LnNH}^{+}$product can be described with usual formal atomic oxidation states: $\mathrm{Ln}(\mathrm{III}), \mathrm{N}(-\mathrm{III})$ and $\mathrm{H}(\mathrm{I})$ corresponding to their column in the periodic table; however, this is not enough to explain the stability of $\mathrm{LnNH}^{+}$, since Reaction 1 
was experimentally observed only for those f-block mono-cations with low electron-promotion energies.

Herein, we report computational studies of the electronic structure of $\mathrm{LnNH}^{+}$for $\mathrm{Ln}=\mathrm{La}, \mathrm{Eu}$ and $\mathrm{Gd} . \mathrm{Eu}^{+}$and $\mathrm{Gd}^{+}$have different reactivities: ${ }^{[1,5]}$ the electronic structure of $\mathrm{LnNH}^{+}$turned out to be that of a d-element only for those lanthanides (La and Gd) for which Reaction 1 was experimentally observed, while such an electronic structure is not possible for $\mathrm{Eu}^{+}$, a mono-cation of low reactivity. ${ }^{[1 \mathrm{a}, 5]}$ Actinide mono-cations $\left(\mathrm{An}^{+}\right)$are also compared. More details on mass spectrometry results, reaction mechanism (Figure.1) and potential energy surfaces will be given elsewhere together with higher level of calculations: MP2, CCSD(T), CASPT2 confirming that DFT/B3LYP is enough for the calculations presented here. ${ }^{[5]}$

\section{Results and Discussion}

$\mathrm{LnNH}^{+}$is linear with $\mathrm{Ln}-\mathrm{N}$ bond lengths of $1.88 \AA$ (La) and $1.83 \AA$ (Gd) (Table 1). These bond lengths are not unexpected as compared with published Sc-N (1.71 $\mathrm{A})$ and Y-N (1.85 $)$ distances $^{[6]}$. Ma et al ${ }^{[7]}$ found a Ce-N bond length $(1.92 \AA)$ longer than the La-N one by $0.04 \AA$ : virtually the same distance is indeed expected, since $\mathrm{Ce}$ is just after $\mathrm{La}$ in the $\mathrm{Ln}$ series. The $\mathrm{Ln}-\mathrm{N}$ bond length is the shortest in $\mathrm{LnNH}^{+}$as compared in all the intermediate species we calculated. ${ }^{[5]} \mathrm{We}$ calculated that the $\mathrm{LaNH}^{+}$geometry is more stable by $400 \mathrm{~kJ} \mathrm{~mol}^{-1}$ than the $\mathrm{HLaN}^{+}$one.

The linear geometry of $\mathrm{LnNH}+$ suggests the sp hybridization for $\mathrm{N}$, thus associated with a $\mathrm{Ln} \equiv \mathrm{N}$ triple bond. Indeed, the NBO5.9 population analysis finds the $(\mathrm{La} \equiv \mathrm{N}-\mathrm{H})^{+}$Lewis structure; namely four covalent bonds (Table 2).

The participation of the $\mathrm{Ln} 4 \mathrm{f}$ orbitals is small: $16 \%$ (La) or $8 \%$ $(\mathrm{Gd})$. As expected, the $\sigma$-valence orbitals are lower in energy than the $\pi$-ones -which are the HOMOs, and the less nodal planes the lower is the energy among the $\sigma$-valence orbitals (Figure. 2 and Table 2). Hui-Zhen et al. ${ }^{[6 b]}$ also reported a linear structure for $\mathrm{YNH}^{+}$with a $\mathrm{Y} \equiv \mathrm{N}$ triple bond formed by $\mathrm{Y}$ s- and d-orbitals, and $\mathrm{N}$ s- and p-orbitals. According to the octet rule, the maximum possible number of covalent bonds is here formed in Lewis interpretations, since the $\mathrm{NH}$ fragment cannot form more than 3 covalent bonds corresponding to the sp hybridization.

To check the influence of f-orbitals, we also suppressed the ffunctions from the basis set, and we re-optimized the geometry of $\mathrm{LaNH}^{+}$. NBO5.9 still found the $(\mathrm{La} \equiv \mathrm{N}-\mathrm{H})^{+}$Lewis structure, despite the La-N distance is larger by $0.10 \AA$, and the complex is destabilized by $115 \mathrm{~kJ} \cdot \mathrm{mol}^{-1}$. This compares well with similar calculations across the $\mathrm{ThO}_{2}, \mathrm{PaO}_{2}{ }^{+}, \mathrm{UO}_{2}{ }^{2+}$ seemingly isoelectronic series: ${ }^{[8]}$ adding f-functions decreased the $\mathrm{Th} \equiv \mathrm{O}$ bond length by $0.12 \AA$, and stabilized the complex by $376 \mathrm{~kJ} \cdot \mathrm{mol}^{-1}\left(138 \mathrm{~kJ} \cdot \mathrm{mol}^{-1}\right.$ per $\mathrm{Th} \equiv \mathrm{O}$ bond), while the influence is more important for $\mathrm{Pa}$ and U. After others, this was an argument to indicate that Th(IV) is rather a d-element in $\mathrm{ThO}_{2}$, while the isoelectronic transthorium elements are true f-block elements in the corresponding molecular ions. The effects of the f-orbitals appear to be of the same order of magnitude: slightly (20\%) smaller for both energy and geometry for the $\mathrm{La} \equiv \mathrm{N}$ triple bond than for the $\mathrm{Th} \equiv \mathrm{O}$ one confirming that the importance of f-type functions is moderate for $\mathrm{LaNH}^{+}$. In $\mathrm{LaNH}^{+}$ and $\mathrm{GdNH}^{+}$, the $\mathrm{N} 2 \mathrm{~s} 2 \mathrm{p}$ orbitals, and the Ln 5d orbitals participate to the triple bonds. $\mathrm{Ln}-\mathrm{N}$ bonding has a predominant d-character. In that respect, these $\left(\mathrm{La}^{+}\right.$and $\left.\mathrm{Gd}^{+}\right)$so called $4 \mathrm{f}$-block monocations actually have chemical behaviours of d-block elements: they form covalent bonds, which all have a dominating d-character. Furthermore, the $\mathrm{M}$ atomic charges $(\mathrm{M}=\mathrm{Y}, \mathrm{La}$ and $\mathrm{Gd})$ are comparable in $\mathrm{MNH}^{+}$for $\mathrm{La}$ (1.97), Gd (1.92) (Table 1), and as published for Y $(1.94)^{[6 b]}$ consistently with similar participation of the $\mathrm{M}$ electrons in the $\mathrm{M}-\mathrm{N}$ bond. Note that $\mathrm{Y}$ is a d-block element.

$\mathrm{Np}^{+}$is the only actinide mono-cation with zero electronpromotion energy as the $\mathrm{Gd}^{+}$lanthanide mono-cation: ${ }^{[1 \mathrm{~h}]} \mathrm{Gd}^{+}$and $\mathrm{Np}^{+}$both have one s- and one d-valence electrons. $\mathrm{Np}^{+}$have the same reactivity as $\mathrm{Gd}^{+}$both forming $\mathrm{MNH}^{+}(\mathrm{M}=\mathrm{Gd}$ and $\mathrm{Np}$, see supporting information). We calculated that the $\mathrm{Np}-\mathrm{N}$ distance $(1.88 \AA)$ in $\mathrm{NpNH}^{+}$is a little longer than the Gd-N one in $\mathrm{GdNH}^{+}$ $(1.83 \AA)$, in line with the small expansion usually observed from Ln to An ions. ${ }^{[9]}$ The participation of Np 5f-orbitals ( $40 \%$ in the $\sigma$ $\mathrm{Np}-\mathrm{N}$ bond, and $20 \%$ in the two $\pi$ ones) is greater as compared to that of $\mathrm{Gd} 4 \mathrm{f}$ orbitals ( $3 \%$ in the $\sigma$ bond and $8 \%$ in the $\pi$ ones), in line with the less compact geometry of the An 5f-orbitals as compared to the $4 \mathrm{f}$-ones. ${ }^{[10]}$

Several intermediate species make the connection between the $\left(\mathrm{La}^{+}+\mathrm{NH}_{3}\right.$, $)$ reactants and the $\left(\mathrm{LaNH}^{+}\right)$final product. ${ }^{[5]}$ The first intermediate species is $\mathrm{LaNH}_{3}{ }^{+}$. Its optimized geometry is $\mathrm{C}_{3 \mathrm{v}}$ tetrahedral. The La-N distance is larger in $\mathrm{LaNH}_{3}{ }^{+}(2.61 \AA)$ as compared in $\mathrm{LaNH}^{+}(1.88 \AA)$. This corresponds to weaker La-N interaction in $\mathrm{LaNH}_{3}{ }^{+}$as also reflected by the La-N $\sigma$-bond vibrational frequency $\left(283 \mathrm{~cm}^{-1}\right.$ for $\mathrm{LaNH}_{3}{ }^{+}$as compared to $838 \mathrm{~cm}^{-1}$ for $\mathrm{LaNH}^{+}$). This suggests purely electrostatic La-N interaction, or at most single La-N covalent bond. In both cases it corresponds to the $\mathrm{sp}^{3}$ hybridization for $\mathrm{N}$ in $\mathrm{LaNH}_{3}{ }^{+}$.

This is in line with the charge of $\mathrm{La}(0.92)$ : virtually no change in the charge of $\mathrm{La}$ as compared to initial $\mathrm{La}^{+}$. The two electrons initially described as the $\mathrm{N} 2 \mathrm{p}_{\mathrm{z}}$ lone pair in $\mid \mathrm{NH}_{3}$ are now (in La- $\mathrm{NH}_{3}{ }^{+}$) shared with La on its $5 \mathrm{~d}_{\mathrm{z}^{2}}$ orbital, formally corresponding to donation from one of the $2 \mathrm{p}_{\mathrm{z}} \mathrm{N}$ electrons to the $5 \mathrm{~d}_{\mathrm{z}^{2}}$ La orbital (see the scheme for Reaction $\mathrm{La}^{+}+\mathrm{NH}_{3} \rightarrow \mathrm{LaNH}_{3}{ }^{+}$in Figure. 1 and Scheme 1).

The rearrangement of $\mathrm{LaNH}_{3}{ }^{+}$into the $\mathrm{HLaNH}_{2}{ }^{+}$intermediate species is an $\mathrm{H}$ transfer from $\mathrm{NH}_{3}$ to $\mathrm{La}$ breaking an $(\mathrm{N}-\mathrm{H})$ covalent bond of $\mathrm{LaNH}_{3}{ }^{+}$, and making new covalent bonds in $\mathrm{HLaNH}_{2}{ }^{+}(\mathrm{La}=\mathrm{N}$ and La-H). This results in more covalent bonds, and more electron pairing, which decreases the spin multiplicity. La must have the $4 \mathrm{f}^{0} 5 \mathrm{~d}^{1} 6 \mathrm{~s}^{1}$ electronic configuration to make the new $\mathrm{La}=\mathrm{N}$ covalent bond in $\mathrm{HLaNH}_{2}{ }^{+}$(see the scheme for Reaction $\mathrm{LaNH}_{3}{ }^{+} \rightarrow \mathrm{HLaNH}_{2}{ }^{+}$in Figure.1 and Scheme 2). It is in this step that low promotion energy is needed.

$\mathrm{HLaNH}_{2}{ }^{+}$have a planar structure (in line with $\mathrm{sp}^{2}$ hybridization for $\mathrm{N}$, and $\mathrm{La}=\mathrm{N}$ double bond) and five bonds: one $\sigma \mathrm{Ln}-\mathrm{H}$ bond, two $\sigma \mathrm{N}-\mathrm{H}$ bonds (one for each of the two $\mathrm{H}$ atoms bonded to $\mathrm{N}$ ), one $\sigma \mathrm{Ln}-\mathrm{N}$ bond (La 6s $5 \mathrm{p} 5 \mathrm{~d} / \mathrm{N} 2 \mathrm{~s} 2 \mathrm{p}$ ) and one $\pi \mathrm{Ln}-\mathrm{N}$ bond ( $\mathrm{La}$ $5 \mathrm{~d} / \mathrm{N} 2 \mathrm{p})$. The $4 \mathrm{f}$ orbitals slightly participate ( $16 \%$ for La and $4 \%$ for Gd) to the $\sigma \mathrm{Ln}-\mathrm{N}$ bonds.

$\mathrm{LaNH}^{+}$can further be formed -from $\mathrm{HLaNH}_{2}{ }^{+}$- via $\mathrm{La}\left(\mathrm{H}_{2}\right) \mathrm{NH}^{+}$, a four-center transition state (TS2), where $\mathrm{H}_{2}$ is weakly bonded to $\mathrm{LaNH}^{+}$by both its La and $\mathrm{N}$ atoms (Figure.1). The charges of $\mathrm{H}_{\mathrm{N}}$ and $\mathrm{H}_{\mathrm{La}}$ are +0.5 and -0.5 respectively. They further attract each other to finally form $\mathrm{H}_{2}$ : $\mathrm{LaNH}^{+}$is formed with $\mathrm{H}_{2}$ loss.

$\mathrm{Eu}$ is just before $\mathrm{Gd}$ in the periodic table; for this reason, differences in their chemical behaviours cannot essentially be originated in the sizes of their ions when at the same oxidation state: it should rather be originated in differences in their electronic configurations. $\mathrm{Eu}^{+}$has the highest electron-promotion energy (388 $\mathrm{kJ} . \mathrm{mol}^{-1}$ ) among the $\mathrm{Ln}^{+}$cations from the $4 \mathrm{f}^{7} 6 \mathrm{~s}^{1}$ to the $4 \mathrm{f}^{6} 5 \mathrm{~d}^{1} 6 \mathrm{~s}^{1}$ electronic configuration. This high value is not unexpected: in the ground state of $\mathrm{Eu}^{+}$the $4 \mathrm{f}$ sub-layer is half occupied conferring a great stability to this fundamental electronic configuration $\left(4 \mathrm{f}^{7} 6 \mathrm{~s}^{1}\right)$. In the $\mathrm{EuNH}_{3}{ }^{+}$initial complex Eu has only one non-f-electron, a $6 \mathrm{~s}$ electron, which would pair with an $\mathrm{H} 1$ s electron giving the $\mathrm{Eu}-\mathrm{H}$ 
covalent bond if $\mathrm{HEuNH}_{2}^{+}$would form, but one electron would remain unpaired on $\mathrm{N}$, since the $4 \mathrm{f}$ to $5 \mathrm{~d}$ promotion energy is too high to allow the formation of a second Eu-N bond (see the scheme for Reaction $\mathrm{EuNH}_{3}{ }^{+} \rightarrow \mathrm{HEuNH}_{2}{ }^{+}$in Figure.1 and Scheme 3) consistently with the NBO population analysis that gives one $\sigma$ Eu$\mathrm{N}$ bond in $\mathrm{HEuNH}_{2}{ }^{+}$, as also found for Eu- $\mathrm{NH}_{3}{ }^{+}$.

$\mathrm{HEuNH}_{2}{ }^{+}$is calculated to have a non planar structure indicating that $\mathrm{N}$ is not in the $\mathrm{sp}^{2}$ hybridization: $\mathrm{Ln}-\mathrm{N}$ cannot be a double bond. Finally, all this suggests that the $\mathrm{HEuNH}_{2}{ }^{+}$geometry is not much stable because the electronic configuration of Eu does not enough facilitate covalency for the Eu-N bond in $\mathrm{HEuNH}_{2}{ }^{+}$. It is further confirmed in the $\mathrm{EuNH}^{+}$species where the $\mathrm{Eu}=\mathrm{N}$ bond is only a double bond. This confirms that the formation of $\mathrm{HLnNH}_{2}{ }^{+}$ is the step, where the electron-promotion energy plays a key role.

$\mathrm{Am}$ is the An with the same electronic configuration as Eu. They each have high electron-promotion energy, and the f-sublayer is half occupied conferring a great stability to this fundamental electronic configuration. We calculated that the Am-N distance $(2.16 \AA)$ in $\mathrm{AmNH}^{+}$is the same for Eu-N in $\mathrm{EuNH}^{+}(2.16$ $\AA$ ). They have similar electronic structures with double $A n=N$ bonds, in line with their similar reactivities: $\mathrm{AnNH}^{+}$is not formed for $\mathrm{An}=\mathrm{Eu}$ and Am species (see supporting information).

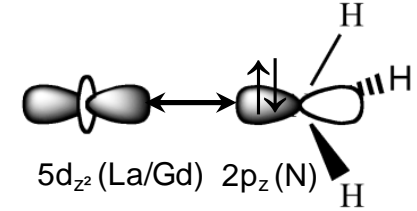

Scheme 2

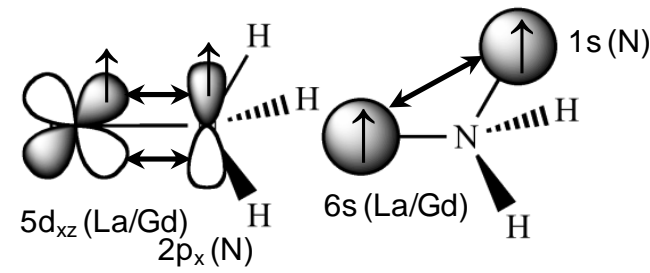

Scheme 3

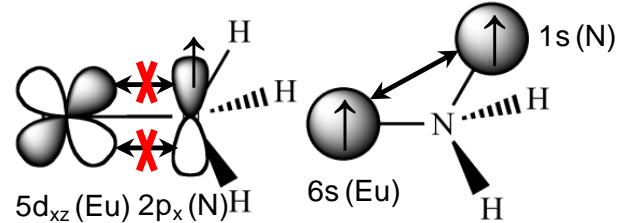

Figure.1. Scheme of reaction $\mathrm{Ln}^{+}+\mathrm{NH}_{3} \rightarrow \mathrm{LnNH}^{+}+\mathrm{H}_{2}$ for $\mathrm{La}^{+} / \mathrm{Gd}^{+}$(a) and $\mathrm{Eu}^{+}$(b). Transition states are in [ ]. The dot $(\bullet)$ represents a valence electron The (actually f-unpaired) electrons that do not participate to the bonding are not represented. The limiting step for the reaction of Eu is represented by the red cross: the spin crossing (SC) reaction is the key steps that requires low electron-promotion energy. Dotted arrows are for reactions that are not observed

a) $\mathbf{L n}=\mathbf{L a}^{+}$and $\mathbf{G d}^{+}$

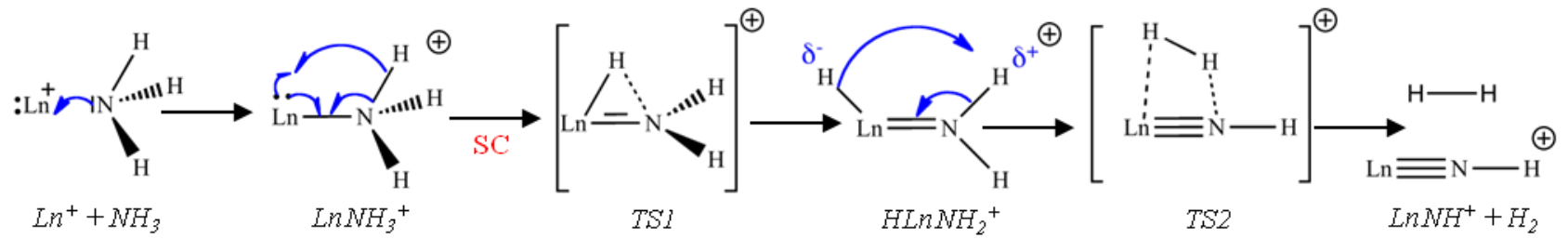

b) $\mathbf{L n}=\mathbf{E} \mathbf{u}^{+}$<smiles>CCCCCCCC</smiles>

$E u^{+}+N_{3}$<smiles>CNC1CCCCCC1</smiles>

$\mathrm{EuNH}_{3}{ }^{+}$

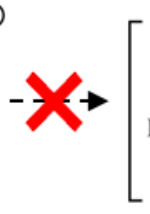<smiles>CN(C)[13CH]</smiles>

TS1<smiles>[CH]CC</smiles>

$\mathrm{HEUNH}_{2}^{+}$

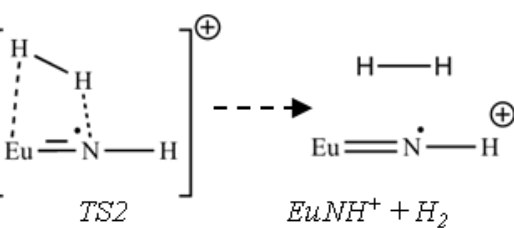




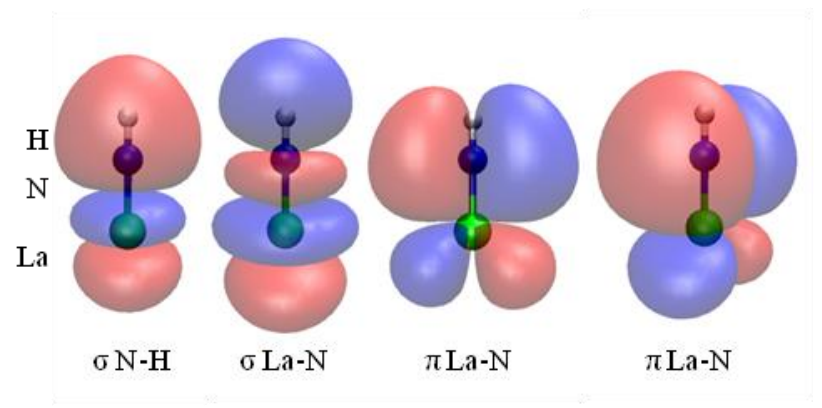

Figure.2. Molecular valence orbitals of $\mathrm{LaNH}^{+}$

Table 1. Electronic configuration and electron-promotion energy $(\mathrm{PE})^{[\mathrm{h}]}$ in kJ.mol ${ }^{-1}$ of $\mathrm{M}^{+}$. M-N bond length (in $\AA$ ), M NBO5.9 charge and $v_{\sigma} \mathrm{M}-\mathrm{N}$ harmonic vibrational frequency $\left(\right.$ in $\mathrm{cm}^{-1}$ ) in $\mathrm{MNH}^{+}$

\begin{tabular}{llllll}
\hline $\mathrm{M}^{+}$ & $\begin{array}{l}\text { Elec. } \\
\text { Conf. }\end{array}$ & PE & $\mathrm{d}(\mathrm{M}-\mathrm{N})$ & $\mathrm{M}$ charge & $v_{\sigma} \mathrm{M}-\mathrm{N}$. \\
\hline $\mathrm{La}^{+}$ & $4 \mathrm{f}^{0} 5 \mathrm{~d}^{2}$ & 19 & 1.88 & 1.98 & 838 \\
$\mathrm{Eu}^{+}$ & $4 \mathrm{f}^{7} 6 \mathrm{~s}^{1}$ & 388 & 2.16 & 1.83 & 575 \\
$\mathrm{Gd}^{+}$ & $4 \mathrm{f}^{7} 5 \mathrm{~d}^{1} 6 \mathrm{~s}^{1}$ & 0 & 1.83 & 1.92 & 850 \\
$\mathrm{~Np}^{+}$ & $5 \mathrm{f}^{4} 6 \mathrm{~d}^{1} 7 \mathrm{~s}^{1}$ & 0 & 1.88 & 1.93 & 862 \\
$\mathrm{Am}^{+}$ & $5 \mathrm{f}^{7} 7 \mathrm{~s}^{1}$ & 245 & 2.16 & 1,70 & 574 \\
\hline
\end{tabular}

Table 2. Molecular orbitals of of $\mathrm{LaNH}^{+}$, energy (E) is in $\mathrm{eV} \cdot \mathrm{LaNH}^{+}$is linear along the $\mathrm{z}$ axis.

\begin{tabular}{llllll}
\hline E & $\begin{array}{c}\text { Main } \\
\text { character }\end{array}$ & Sym. & La & $\mathrm{N}$ & $\mathrm{H}$ \\
\hline-23.0 & $\sigma \mathrm{N}-\mathrm{H}$ & $\mathrm{A} 1$ & $6 \mathrm{~s} 5 \mathrm{~d}_{\mathrm{z}^{2}}$ & $2 \mathrm{~s} 2 \mathrm{pz}$ & $1 \mathrm{~s}$ \\
-20.4 & $\sigma \mathrm{La}-\mathrm{N}$ & $\mathrm{A} 1$ & $5 \mathrm{dz}^{2} 4 \mathrm{fz}\left(5 \mathrm{z}^{2}-3 \mathrm{r}^{2}\right)$ & $2 \mathrm{~s} 2 \mathrm{pz}$ & $1 \mathrm{~s}$ \\
-11.5 & $\pi$ La-N & E1 & $5 \mathrm{dxy} 4 \mathrm{fx}\left(5 \mathrm{z}^{2}-3 \mathrm{r}^{2}\right)$ & $2 \mathrm{px}$ & \\
-11.5 & $\pi$ La-N & E1 & $5 \mathrm{dyz} 4 \mathrm{fy}\left(5 \mathrm{z}^{2}-\mathrm{r}^{2}\right)$ & $2 \mathrm{py}$ & \\
\hline
\end{tabular}

\section{Conclusions}

In conclusion, the original MOs used for the quantum calculations evidence covalent bonding with dominant d-character for the contributions of $\mathrm{Ln}=\mathrm{La}$ and $\mathrm{Gd}$ in compounds along their reaction pathway. This is confirmed by NBO5.9 population analysis. $\mathrm{Ln}^{3+}$ hard trications can be viewed as $\mathrm{La}^{3+}$-which does not have any valence electron- where the extra electrons are usually added onto $4 \mathrm{f}$-orbitals that do not participate to the bonding. Double reduction of some $\mathrm{Ln}^{3+}$ ions into $\mathrm{Ln}^{+}$-typically $\mathrm{La}^{+}$and $\mathrm{Gd}^{+}$- can bring one electron in an s-orbital, and another one in a dorbital participating to covalent bonds as for the $\mathrm{Sc}^{+}$and $\mathrm{Y}^{+} \mathrm{d}-$ block ions of transition elements: $\mathrm{Sc}^{+}$and $\mathrm{Y}^{+}$are isoelectronic to $\mathrm{La}^{+}$in $\mathrm{M} \equiv \mathrm{NH}^{+}$. The same is here calculated for $\mathrm{Np}^{+}$, an $\mathrm{An}^{+} 5-\mathrm{f}$ block cation with two non-f electrons in its ground state $\left(5 \mathrm{f}^{4} 6 \mathrm{~d}^{1} 7 \mathrm{~s}^{1}\right)$.
Supporting Information (see footnote on the first page of this article)

$[1]$

a) G. K. Koyanagi, P. Cheng, D. K. Bohme, Journal of Physical Chemistry A 2010, 114, 241-246; b) V. Blagojevic, E. Flaim, M. J. Y. Jarvis, G. K. Koyanagi, D. K. Bohme, International Journal of Mass Spectrometry 2006, 249, 385-391; c) P. Cheng, D. K. Bohme, Inorganic Chemistry 2006, 45, 7856-7863; d) G K. Koyanagi, D. K. Bohme, Journal of Physical Chemistry A 2001, 105, 8964-8968; e) P. Cheng, G. K. Koyanagi, D. K. Bohme, Journal of Physical Chemistry A 2006, 110, 12832 12838; f) J. B. Schilling, J. L. Beauchamp, Journal of the American Chemical Society 1988, 110, 15-24; g) H. H. Cornehl, C. Heinemann, D. Schroder, H. Schwarz, Organometallics 1995 , 14, 992-999; h) J. K. Gibson, Journal of Physical Chemistry 1996, 100, 15688-15694; i) J. A. Carretas, J. Marcalo, A. P. de Matos, International Journal of Mass Spectrometry 2004, 234, 51-61; j) A. Shayesteh, V. V. Lavrov, G. K. Koyanagi, D. K Bohme, Journal of Physical Chemistry A 2009, 113, 5602-5611.

a) M. A. Tolbert, J. L. Beauchamp, Journal of the American Chemical Society 1984, 106, 8117-8122; b) Y. Huang, M. B. Wise, D. B. Jacobson, B. S. Freiser, Organometallics 1987, 6, 346-354; c) R. Kretschmer, M. Schlangen, H. Schwarz, Chemistry-a European Journal 2012, 18, 40-49.

O. Eisenstein, L. Maron, Journal of Organometallic Chemistry 2002, 647, 190-197.

a) R. D. Shannon, Acta Crystallographica Section A 1976, 32, 751-767; b) P. D'Angelo, A. Zitolo, V. Migliorati, G. Chillemi, M. Duvail, P. Vitorge, S. Abadie, R. Spezia, Inorganic Chemistry 2011, 50, 4572-4579.

A. Quemet. R. Brennetot, P. Vitorge, C. Marsden, J.Y Salpin, R. Spezia, M.P. Gaigeot, J. Tortajada, A. Cimas, S. Liu, L. Gagliardi; to be submitted for publication.

a) N. Russo, E. Sicilia, Journal of the American Chemical Society 2001, 123, 2588-2596; b) L. Hui-Zhen, W. Yong-Cheng, G. Zhi-Yuan, Z. Qing-Li, W. Qing-Yun, S. Yu-Bing, Journal of Molecular Structure: THEOCHEM 2008, 866, 5-10.

W. P. Ma, Y. C. Wang, L. L. Lv, Y. Z. Jin, J. Y. Nian, D. F. Ji, C. L. Wang, M. J. La, X. B. Wang, Q. Wang, Computational and Theoretical Chemistry 2011, 977, 69-77.

B. Siboulet, C. J. Marsden, P. Vitorge, New Journal of Chemistry 2008, 32, 2080-2094.

[9] P. Pyykko, Chemical Reviews 1988, 88, 563-594.

[10] M. Dolg, Encyclopedia of Computational Chemistry, John Wiley \& Sons. 1998

Received: ((will be filled in by the editorial staff)) Published online: ((will be filled in by the editorial staff))

\section{Experimental Section}

Computational and experimental details are given in the Supporting Information 


\section{Entry for the Table of Contents}

Triple $\mathrm{M} \equiv \mathrm{N}$ bond

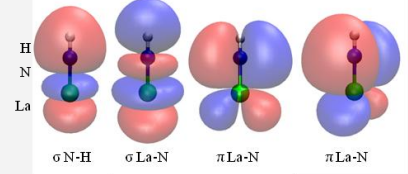

Quemet A., Brennetot R., Salpin J.Y., Cimas A., Tortajada J., Marsden C, and Vitorge P...... Page No. - PageNo.

$\mathrm{M} \equiv \mathrm{N}$ triple bonds of essentially d-

How can f-Block Mono-Cations Behave character are formed for lanthanide $(\mathrm{M}=$ $\mathrm{La}$ and $\mathrm{Gd})$ and actinide $(\mathrm{M}=\mathrm{Np}) \mathrm{f}$ block elements explaining why $\mathrm{La}^{+}, \mathrm{Gd}^{+}$ and $\mathrm{Np}^{+}$behave like d-mono-cations as experimentally evidenced by mass spectrometry, and why their reactivities are correlated with their electronas Mono-Cations of d-Block Transition Elements?

Keywords: Density functional calculations / Ion-molecule reactions / Lanthanides / Actinides / Multiple bonds promotion energies. 


\title{
How can f-Block Mono-Cations Behave as Mono-Cations of d-Block Transition Elements?
}

\author{
Alexandre Quemet, Rene Brennetot, Jean-Yves Salpin, Alvaro Cimas, Colin Marsden, Jeanine \\ Tortajada, and Pierre Vitorge*
}

Computational methods: The quantum calculations were performed with the Gaussian03 suite of programs. ${ }^{[1]}$ The geometries and the natural population analysis of the stationary points on the potential energy profiles have been obtained with DFT/B3LYP calculations, this level of calculation compares well with MP2, $\operatorname{CCSD}(\mathrm{T})$ and $\mathrm{CASPT} 2$ (as described in the companion paper: ref.5 of the communication) for the data presented here.

The Stuttgart's small core relativistic effective core potentials ECP28MWB with 28 core electrons were used for the Ln atoms. ${ }^{[2]}$ We call STUTf, the ECP28MWB_SEG associated basis where the gfunctions have been suppressed. They were used for the (B3LYP) geometry optimizations, and to extract the electronic structures. 2 g-functions were added for the MP2 and $\operatorname{CCSD}(\mathrm{T})$ calculations (see ref.5 of the communication). The $6-31+\mathrm{G}(\mathrm{d}, \mathrm{p})$ basis set was used for $\mathrm{N}$ and $\mathrm{H}$. Similarly, we note STUT_no_f_no_g the STUTf basis set from which the f-functions are suppressed.

Electronic configuration, spin contamination, energy difference between the highest occupied (HUMO) and the lowest unoccupied (LUMO) molecular orbitals, vibrational frequencies, and other usual calculation results were examined to check the quantum calculations. Natural population analysis (NPA) was performed with software NBO5.9, ${ }^{[3]}$ which also provides atomic charges. However, we are essentially discussing the mono- (or bi- for close shell calculations) electronic Molecular Orbitals (MO) used and produced by the B3LYP/STUTf quantum calculations called MOs when nothing else is stated. The molecular graphic package Visual Molecular Dynamics ${ }^{[4]}$ was used for visualizing geometries, and molecular orbitals with an isosurface value of 0.01 atomic unit from Gaussian03 cube files. 
Experimental methods: Mass spectrometry measurements were carried out with a single quadrupole ICP-MS X Series I and Serie II (Thermo-Fisher Scientific, Bremen, Germany) equipped with the Collision Cell Technology (CCT). Main operating parameters are resumed in Table S1.The ICP-MS X serie I has been modified in order to work with radioactive materials. A glove box (JACOMEX, Dagneux, France) has been installed for this purpose. The nebulizer, the peristaltic pump, the plasma ion source, and the interface are located inside the glove box. An autosampler CETAX ASX 260 also situated inside the glove box, and controlled by the PlasmaLab software (Thermo Electron) minimizes human irradiation. Air tightness is ensured by a modified interface, and the pumping system was also adapted. A new pump was added (EDWARDS $65 \mathrm{~m} 3 \mathrm{~h}-1$ ) from the standard configuration to ensure a better vacuum in the expansion, and to compensate the head losses due to the addition of filters.

\section{Table S1. Typical ICP-MS operating conditions}

\begin{tabular}{ccc}
\hline & $\begin{array}{c}\text { Q ICP-MS } \\
\text { X serie I } \\
\text { (Thermo Fischer) }\end{array}$ & $\begin{array}{c}\text { Q ICP-MS } \\
\text { X serie II } \\
\text { (Thermo Fischer) }\end{array}$ \\
\hline RF power & $1400 \mathrm{~W}$ & $1250 \mathrm{~W}$ \\
\hline Plasma gas flow rate & $14 \mathrm{~L} \cdot \mathrm{min}^{-1}$ & $14 \mathrm{~L} \cdot \mathrm{min}^{-1}$ \\
Auxiliary gas flow rate & $0.8 \mathrm{~L} \cdot \mathrm{min}^{-1}$ & $0.75 \mathrm{~L} \cdot \mathrm{min}^{-1}$ \\
Nebulizer gas flow rate & $0.85 \mathrm{~L} \cdot \mathrm{min}^{-1}$ & $0.84 \mathrm{~L} \cdot \mathrm{min}^{-1}$ \\
Sample uptake rate & $0.4 \mathrm{~mL} \cdot \mathrm{min}^{-1}$ & $1 \mathrm{~mL} \cdot \mathrm{min}^{-1}$ \\
Nebulizer type & $\begin{array}{c}\text { Quartz concentric } \\
\text { Conical with impact } \\
\text { bead }\end{array}$ & $\begin{array}{c}\text { Quartz concentric } \\
\text { Quartz chamber with } \\
\text { impact bead }\end{array}$ \\
\hline
\end{tabular}

Many elements can be analyzed in standard mode, i.e. without gas in the cell. Nevertheless, interferences can complicate the analysis, especially for nuclear fuels, where elements are not with their natural isotopic compositions. Collision/reaction devices are currently used to get rid of such interferences. This system is based on addition of collision and/or reaction gas after cation formation. The gas impacts or reacts with ion beam eliminating isobaric or poly-atomic interference. The ion lens setting, the nebulizer gas-flow rate and the torch position of the instrument were optimized every day with a multi element tuning solution (SPEX) in standard mode. This solution contains $1 \mu \mathrm{g} . \mathrm{L}^{-1}$ of uranium and indium. It is used to maximize sensitivity, and to perform short term stability tests. Typical sensitivities were better than 150,000 counts. $\mathrm{s}^{-1} \cdot \mu \mathrm{g}^{-1} \cdot \mathrm{L}$ (X serie II) and 300,000 counts. $\mathrm{s}^{-1} \cdot \mu \mathrm{g}^{-1} \cdot \mathrm{L}$ (X serie 
I) with a residual standard deviation better than $1 \%$ for 10 measurements of 1 minute. In gas mode, a 1 $\mu \mathrm{g} . \mathrm{L}^{-1}$ indium solution -which does not react with gas- was used to maximize sensitivity for each gas flow rate.

$10 \mu \mathrm{g} . \mathrm{L}^{-1} \mathrm{Ln}$ mono-elemental solutions were prepared from $1000 \mathrm{mg} . \mathrm{L}^{-1} \mathrm{La}$ and Eu standard SPEX, and ${ }^{160} \mathrm{Gd},{ }^{237} \mathrm{~Np}$ and ${ }^{241} \mathrm{Am}$ mono-isotopic solutions diluted in a $0.5 \mathrm{~N}$ nitric acid solution. This $0.5 \mathrm{~N}$ nitric acid solution was prepared by diluting a sub-boiling $14.3 \mathrm{~N}$ nitric acid solution with deionized water (resistivity $18.2 \mathrm{M} \Omega \mathrm{cm}$ ). The sub-boiling nitric acid solution was obtained by distillation of a $65 \% \mathrm{HNO}_{3}$ Normatom solution using an EVAPOCLEAN system (Analab, France). Indium has been added in each sample to follow the scattering losses consecutive to the introduction of a gas in the Q ICP-MS reaction cell. Ammonia (minimum purity of 99.98\%) was obtained from MESSER (Puteaux, France). High purity was used to avoid secondary reactions with impurities. Nevertheless, deuterated ammonia $\left(\mathrm{ND}_{3}\right)$ - D isotopic content of $99.75 \%$ - was used to check results obtained with $\mathrm{NH}_{3}$. It was purchased from Euriso-top (Gif-sur -Yvette, France). The gas flow rate was measured with a Mass Flow Controller (MFC), calibrated for He. The flow rate of $\mathrm{NH}_{3}$

$$
\varphi_{\mathrm{NH}_{3}}=\mathrm{f}_{\mathrm{NH}_{3}} \varphi_{\mathrm{He}}
$$

was calculated by using $\mathrm{f}_{\mathrm{NH}_{3}}=0.551$ in our conditions. 

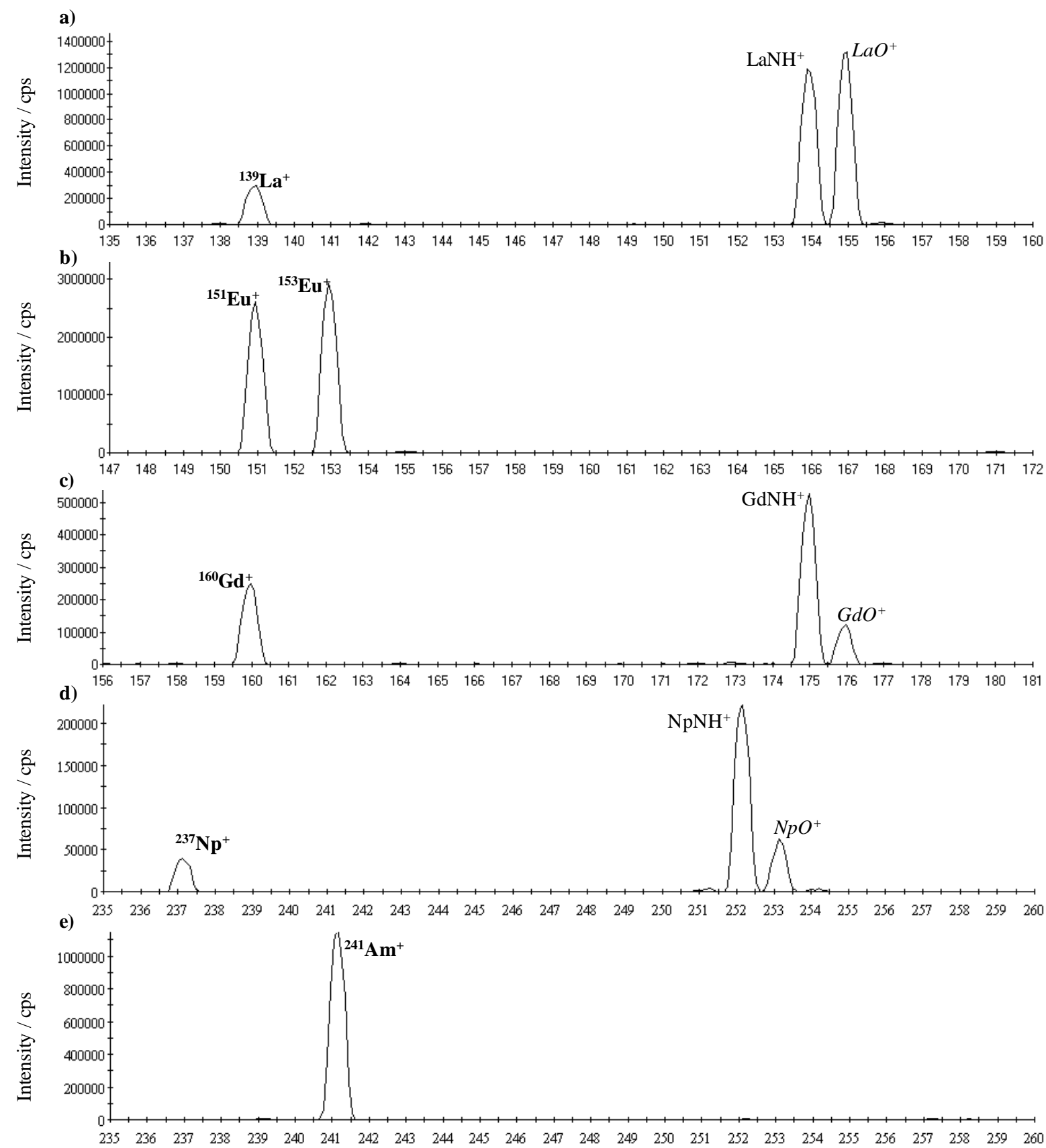

$\mathrm{M} / \mathrm{amu}$

Figure S1. Q ICP-MS mass spectra for $10 \mathrm{ppb}$ of ${ }^{139} \mathrm{La} \mathrm{(a)}$ and Eu (b) standard solutions, and ${ }^{160} \mathrm{Gd}(\mathrm{c}){ }^{237} \mathrm{~Np}(\mathrm{~d})$ and ${ }^{241} \mathrm{Am}(\mathrm{e}) \mathrm{mono}-$ isotopic solutions, when using $\mathrm{NH}_{3}$ as reacting gas $\left(0.05 \mathrm{~mL} . \mathrm{min}^{-1}\right)$. LaO and $\mathrm{GdO}^{+}$arise from secondary reactions with gas impurities as confirmed by using $\mathrm{ND}_{3}$ instead of $\mathrm{NH}_{3}$ (see ref.5 of the communication).

[1] M. J. Frisch, G. W. Trucks, H. B. Schlegel, G. E. Scuseria, M. A. Robb, J. R. Cheeseman, J. A. Montgomery, T. V. Jr., K. N. Kudin, J. C. Burant, J. M. Millam, S. S. Iyengar, J. Tomasi, V. Barone, B. Mennucci, M. Cossi, G. Scalmani, N. Rega, G. A. Petersson, H. Nakatsuji, M. Hada, M. Ehara, K. Toyota, R. Fukuda, J. Hasegawa, M. Ishida, T. Nakajima, Y. Honda, O. Kitao, H. Nakai, M. Klene, X. Li, J. E. Knox, H. P. Hratchian, J. B. Cross, V. Bakken, C. Adamo, J. Jaramillo, R. Gomperts, R. E. Stratmann, O. Yazyev, A. J. Austin, R. Cammi, C. Pomelli, J. W. Ochterski, P. Y. Ayala, K. Morokuma, G. A. Voth, P. Salvador, J. J. Dannenberg, V. G. Zakrzewski, S. Dapprich, A. D. Daniels, M. C. Strain, O. Farkas, D. K. Malick, A. D. Rabuck, K. Raghavachari, J. B. Foresman, J. V. Ortiz, Q. Cui, A. G. Baboul, S. Clifford, J. Cioslowski, B. B. Stefanov, G. Liu, A. Liashenko, P. Piskorz, I. Komaromi, R. L. Martin, D. J. Fox, T. Keith, M. A. Al-Laham, C. Y. Peng, A. Nanayakkara, M. Challacombe, P. M. W. Gill, B. Johnson, W. Chen, M. W. Wong, C. Gonzalez, J. A. Pople, Gaussian 03, Revision E.01, Gaussian Inc. Wallingford CT, 2004.

[2] a) X. Y. Cao, M. Dolg, Journal of Chemical Physics 2001, 115, 7348-7355; b) X. Y. Cao, M. Dolg, Journal of Molecular Structure-Theochem 2002, 581, 139-147; c) M. Dolg, H. Stoll, H. Preuss, Theoretica Chimica Acta 1993, 85, 441-450.

[3] NBO5.9, E. D. Glendening, J. K. Badenhoop, A. E. Reed, J. E. Carpenter, J. A. Bohmann, C. M. Morales, F. Weinhold, U. o. W. (Theoretical Chemistry Institute, Madison, WI, 2009); http://www.chem.wisc.edu/ nbo5. 
[4] W. Humphrey, Dalke, A. and Schulten, K., "VMD - Visual Molecular Dynamics", J. Molec. Graphics, 1996, vol. 14, pp. $33-38$. 